\title{
FEATURES OF COMPETITION IN THE CONTEXT OF DIGITALIZATION OF THE ECONOMY
}

\author{
${ }^{\odot 2020}$ TIUTIUNNYKOVA S. V., RIABOVOL D. A.
}

UDC 338.12.017

JEL: L86; M21

\section{Tiutiunnykova S. V., Riabovol D. A. Features of Competition in the Context of Digitalization of the Economy}

Dynamic changes in the market bases of the economy under the influence of digital technologies are displayed. Logistics, minimizing transaction costs, speeding up the process of circulation are the benefits that the digital economy brings. All these factors coexist with a number of serious threats. Digital formalization and desocialization of economic activity, concentration of information power and increased consumer manipulation lead to a fundamental social uncertainty. Institutional changes are supposed to remove growing uncertainty and risks by ensuring the safety and freedom of consumer choice. The changes in the list of the world's largest companies by capitalization since 2008 illustrate the growing importance of the high-tech industry on a global scale. The article shows the tendencies of formation of the market imbalances in the market shares of players in certain areas of the digital economy, and provides examples of expanding the scope of presence through the acquisition of smaller start-ups with significant innovative potential. Removing the uncertainty of socio-economic development as well as reducing gaps due to incomes or education lies in the plane of social control on the part of society over the dynamic technological and economic changes. Only a mature society is able to form the quality of the institutional environment in which it becomes possible: firstly, to extract the maximum result from modern technologies; secondly, to distribute it on the fair basis; thirdly, to keep a person's habitat comfortable for his life. The digital economy should serve human development and well-being, not virtualize a human and subdue him the newest technology. Formation of new institutional mechanisms to counter unfair competition were needed, which would be the prospect of further research into the problem.

Keywords: digital economy, competition, economic power, institutionalization, digitalization.

DOI: $h$ ttps://doi.org/10.32983/2222-4459-2020-3-253-259

Tabl.: 2. Bibl.: 18.

Tiutiunnykova Svitlana V. - D. Sc. (Economics), Professor, Professor of the Department of Economic Theory and Economic Methods of Management, V. N. Karazin Kharkiv National University (4 Svobody Square, Kharkiv, 61022, Ukraine)

E-mail: svetatutunnikova@gmail.com

ORCID: https://orcid.org/0000-0003-3680-9023

Researcher ID: http://www.researcherid.com/F-8738-2019

SPIN: http://elibrary.ru/8071-0459

Riabovol Dmytro A. - Bachelor of Economics, V. N. Karazin Kharkiv National University (4 Svobody Square, Kharkiv, 61022, Ukraine)

E-mail: dimaruabovol@gmail.com

ORCID: http://orcid.org/0000-0002-6054-5155

УДК 338.12.017

JEL: L86; M21

Тютюнникова С. В., Рябовол Д. А. Особливості конкурентної боротьби в умовах цифровізації економіки

Показано динамічні зміни ринкових засад функиіонування економіки під впливом цифрових технологій. Логістика, мінімізація трансакційних витрат, прискорення процесів обігу - переваги, які несе цифрова економіка. Всі ці фактори існують поряд з низкою серйозних загроз. Цифрова формалізація та десоціалізація господарської діяльності, концентрація інформаційної влади та розширення практики маніпулювання споживачем ведуть до фундаментальної соціальної невизначеності. Інституційні зміни покликані зняти зростаючу невизначеність і ризики, забезпечивши безпеку та свободу вибору споживача. зміни в списку найбільших за капіталізацією компаній світу, що відбулися за період з 2008 р., ілюструють зростаюче значення індустрії високих технологій в глобальному маситабі. У статті показано тенденції формування диспропорцій ринкових часток гравиів окремих сфер цифрової економіки, наведено приклади розширення сфер присутності за рахунок придбання більш дрібних стартапів, які володіють значним інноваційним потенціалом. Зняття невизначеності соціально-економічного розвитку та розривів у рівнях доходів, освіті лежить у площині соціального контролю з боку суспільства над динамічними технологічними й економічними змінами. Тільки зріле суспільство здатне сформувати якість інституційного середовища, при якому стає можливим: по-перше, отримати від сучасних технологій максимальний результат; по-друге, справедливо розподілити його; по-третє, зберегти середовище проживання людини комфортним для життя. Цифрова економіка повинна служити людському розвитку та добробуту, а не віртуалізовувати та підпорядковувати людину новітнім технологіям. Необхідно формування нових інституційних механізмів протидії елементам недобросовісної конкуренції, що і є перспективою подальших досліджень даної проблеми.

Ключові слова: цифрова економіка, конкуренція, економічна влада, інститучіоналізація, діджиталізація.

Табл.: 2. Бібл.: 18.

Тютюнникова Світлана Володимирівна - доктор економічних наук, професор, професор кафедри економічної теорії та економічних методів управління, Харківський національний університет ім. В. Н. Каразіна (пл. Свободи, 4, Харків, 61022, Україна)

E-mail: svetatutunnikova@gmail.com

ORCID: https://orcid.org/0000-0003-3680-9023

Researcher ID: http://www.researcherid.com/F-8738-2019

SPIN: http://elibrary.ru/8071-0459

Рябовол Дмитро Анатолійович - бакалавр економічного факультету, Харківський національний університет ім. В. Н. Каразіна (пл. Свободи, 4, Харків, 61022, Україна)

E-mail: dimaruabovol@gmail.com

ORCID: http://orcid.org/0000-0002-6054-5155 
Показаны динамические изменения рыночных основ функционирования экономики под воздействием цифровых технологий. Логистика, минимизация трансакционных издержек, ускорение процесса обращения - преимущества, которые несет цифровая экономика. Все эти факторы соседствуют с рядом серьезных угроз. Цифровая формализация и десоциализация хозяйственной деятельности, концентрация информационной власти и расширение практики манипулирования потребителем ведут к фундаментальной социальной неопределенности. Институциональные изменения призваны снять растущую неопределенность и риски, обеспечив безопасность и свободу выбора потребителя. Изменения в списке самых крупных по капитализации компаний мира, произошедшие за период с 2008 г., иллюстрируют нарастающее значение индустрии высоких технологий в глобальном масштабе. В статье показаны тенденции формирования диспропорций рыночных долей игроков отдельных сфер цифровой экономики, приведены примеры расширения сфер присутствия за счет приобретения более мелких стартапов, обладающих значительным инновационным потенциалом. Снятие неопределенности социально-экономического развития и разрывов в уровнях доходов, образовании лежит в плоскости социального контроля со стороны общества над динамическими технологическими и экономическими изменениями. Только зрелое общество способно сформировать качество институциональной среды, при котором становится возможным: во-первых, извлечь из современных технологий максимальный результат; во-вторых, справедливо распределить его; в-третьих, сохранить среду обитания человека комфортной для его жизни. Цифровая экономика должна служить человеческому развитию и благополучию, а не виртуализировать и подчинять человека новейшим технологиям. Необходимо формирование новых институциональных механизмов противодействия элементам недобросовестной конкуренции, что и является перспективой дальнейших исследований данной проблемы.

Ключевые слова: цифровая экономика, конкуренция, экономическая власть, институционализация, диджитализация.

Табл.: 2. Библ.: 18.

Тютюнникова Светлана Владимировна - доктор экономических наук, профессор, профессор кафедры экономической теории и экономических методов управления, Харьковский национальный университет им. В. Н. Каразина (пл. Свободы, 4, Харьков, 61022, Украина)

E-mail: svetatutunnikova@gmail.com

ORCID: https://orcid.org/0000-0003-3680-9023

Researcher ID: $h$ ttp://www.researcherid.com/F-8738-2019

SPIN: http://elibrary.ru/8071-0459

Рябовол Дмитрий Анатольевич - бакалавр экономического факультета, Харьковский национальный университет им. В. Н. Каразина (пл. Свободы, 4, Харьков, 61022, Украина)

E-mail: dimaruabovol@gmail.com

ORCID: http://orcid.org/0000-0002-6054-5155

$\mathrm{T}$ he digital economy is one of the main drivers of development in the 21st century. It is changing not only the IT-sector itself but the face of the world economy, the nature of the future society, also transforming the present. It is especially obvious in the context of competition, where new and large players tend to change the nature of competitive struggle, doing it slowly but steadily.

We can judge of the dynamism of the digitalization by the volume of investments made in innovative startups. The annual volume of investing in startups that allow digitalizing bureaucratic processes and public services is already over USD400 billion. According to the forecast data, the assessment presented in the publication by Director of the Digital Innovation in Government Directorate of the Development Bank of Latin America (CAF), Carlos Santiso [1], in five years, this volume will reach USD1 trillion.

In Europe, over 2,000 startups work in a wide range of fields. For example, the Ada Health application, based on artificial intelligence technologies, makes it possible to get an estimated diagnosis for certain symptoms. The British Novoville application helps contact local authorities. Digitalization of the public sector services allows improving the ratio of their price and quality, reducing corruption, and bringing financial returns.

Large technology companies that provide mostly digital, virtual products and services have gained signifi- cant influence during the previous two decades. Amazon, Facebook, Alphabet, Apple and hundreds of other "unicorns" (companies with a market capitalization of more than USD1 billion) now have unprecedented influence, both economic and social. The products they create are unique and indispensable for their users. The transactions they carry out for the acquisition of new, innovative startups make it possible for them to strengthen their technological superiority.

To a large extent, the driving force behind such active development is the global and ubiquitous distribution of functional and necessary, often even free (or shareware) digital tools and products. For example, using the search engine from Alphabet as such is free, but the user pays a significant part of his/her attention to the advertisement within his/her view (which is also true for the content on individual sites indexed by Google because they earn revenue mainly by using the AdSense service).

The purpose of the article is to reveal the features of the transformation of market competition that arise in the digitalized economy. Analyzing the problems associated with the formation of the digital economy is in the focus of both domestic and foreign economists. According to the authors of the article "Theoretical Approaches to Determining the Digital Economy", the digital economy is an economic activity that arose only due to new digital technologies and is based on the use of digital business models, in which digital (electronic, virtual) data are the 
main means of production [2]. S. M. Veretyuk, V. V. Pilinskiy also draw attention to the importance of defining the digital economy as part of the entire economy, which is dominated by the factor of information, knowledge and intangible assets [3]. The researchers also highlight the concept of a "network economy", meaning by this term a way of organizing economic activity within the framework of a market economy with high informatization [4]. We can divide all technologies within Industry 4.0 into three types: technologies for working with data; technologies for application in production; technologies for interaction with the environment [5].

$\mathrm{T}$ The digitalization of the modern economy is transforming into an integrated technological platform capable of connecting various technologies into hybrid technological processes and all of their entities into a single economic mechanism. However, is everything so positive and promising within the framework of a digital economy that is rapidly developing and dictating new conditions for competition? The strength and speed of the digitalization process mean that large companies increase their capitalization, break away from their competitors, reformat the rules of the game, and change the principles of competition. Tbl. 1 shows a list of the five largest companies by market capitalization at the beginning of 2008 .

Based on the data, we can state that only a little more than a decade ago, the largest public companies by market capitalization were mainly commodity players and telecommunication giants. Certainly, we can carry out such an analysis in a more dynamic format, also tracking the situation of technological companies including Microsoft, which also were often close to the global leadership (during the dot-com boom of 1999). Then, in the wake of bankruptcies within incompletely formed and "overheated" IT-industry, such innovative players suddenly rolled back to many positions. However, we can state that the previous decade was the period of the active development of technological companies, along with their market power.

The past 2019 was marked by the emergence of more than 140 companies with a market capitalization of over USD1 billion (most of them within the technological and Internet industries). The list of the largest companies by market capitalization in the middle of the year (before the Arab oil company Saudi Aramco held its record initial public offering) looks like this ( $T b l .2)$.

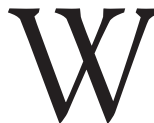
e can see a significant increase in the number of companies with a high level of market power (and capitalization), and no less important, carrying out their development mainly in a new and emerging sphere of Internet solutions, services, and products. Also, according to the table, the total capitalization of the five largest companies in the world has increased from USD1,841 billion in 2008 to USD3,987 billion in 2019 (more than 2.16 times). This growth is the most expressive and clear indicator of the demand for various digital products and services. Some of them (for example, Zappos.com) created separate, previously nonexistent market niches.

Table 1

The largest companies by market capitalization in the world, 2008 (USD billion)

\begin{tabular}{|c|l|l|l|c|}
\hline No. & \multicolumn{1}{|c|}{ Company } & \multicolumn{1}{|c|}{ Country } & \multicolumn{1}{c|}{ Industry } & Market cap., \$bn \\
\hline 1 & ExxonMobil & USA & Oil and Gas & 452 \\
\hline 2 & PetroChina & China & Oil and Gas & 423 \\
\hline 3 & General Electric & USA & $\begin{array}{l}\text { Diversified manufacturing of machinery } \\
\text { and equipment }\end{array}$ & 369 \\
\hline 4 & Gazprom & Russia & Oil and Gas & 299 \\
\hline 5 & China Mobile & Hong Kong & Mobile communications & 298 \\
\hline
\end{tabular}

Source: developed by the authors based on [6].

Table 2

The largest companies by market capitalization in the world, 2019 (USD billion)

\begin{tabular}{|c|l|c|l|c|}
\hline No. & \multicolumn{1}{|c|}{ Company } & Country & \multicolumn{1}{|c|}{ Industry } & Market cap., \$bn \\
\hline 1 & Microsoft & USA & Technology & 905 \\
\hline 2 & Apple & USA & $\begin{array}{l}\text { Computer Hardware, Computer Software, } \\
\text { Consumer Electronics }\end{array}$ & 896 \\
\hline 3 & Amazon.com & USA & E-commerce and Cloud Computing & 875 \\
\hline 4 & Alphabet & USA & Communication Services & 817 \\
\hline 5 & Berkshire Hathaway & USA & Financial Sector & 494 \\
\hline
\end{tabular}

Source: developed by the authors based on [7]. 
The analysis of digital technologies, their sped up development and their conquest of significant segments of the market, as well as the entrance of their products in the daily practice of business and society shows that the market environment is becoming hybrid. Firstly, we can assume that the specifics of digital technology are not associated with large barriers to the entry of new business entities into the market. Indeed, firms enter the market at a reasonably fast pace. However, some of the largest technology corporations keep their almost monopoly market power. As they grow, gaps widen, as compared to smaller and recently formed firms, in many parameters (level of capitalization, number of loyal customers, etc.).

Secondly, digital products and services possess not only monopoly power but also psychological features, creating persistent user habits. This enables firms to accumulate and use their power over consumers, develop and implement their own rules of the game, which are consistent with their interests.

$\mathrm{I}$ is worth considering the main threats and challenges, created mainly by the modern technology companies formed on the wave of the digital revolution, concerning both their competitors and individual users. The research of 2018, conducted by the Jumpshot analytic platform, focuses on the fact that Amazon.com (as of Q1 2018) owns at least 90\% in as many as five separate market niches, namely: home repair and improvement tools; skin care; batteries; accessories for golf, the kitchen and dining room [8]. This state of affairs can often harm competition and make the development of small startups or those players unable to adapt in time to new conditions in the digitalization of trade, very challenging. For example, this was the case with the offline book sales network in the USA, Barnes \& Noble, which could not win in the competition with Amazon.com, even at the very beginning of its active development (when the startup positioned itself "only" as the largest bookstore in the world (unlike the modern slogan The Everything Store)) [9].

Apple's market power is manifested, among other things, in its control over the digital platform for downloading and purchasing applications, Apple Store, which houses various software applications for the entire line of devices of the company. At the moment, we can say that this digital platform has become a crucial tool for the successful communication of many companies with its customers all around the world. Apple has significant control, deciding which players should place their applications for downloading (and receive benefit from it), though it may put into question the transparent competition in this marketplace.

The main and leading players in the modern global market for high-tech solutions are online platforms focused on expanding their client base, often even with no profit during the first years. It is worth noting the influence of network effects, which has a positive impact on the trends in the development of services like Facebook,
Amazon, Instagram, TikTok, etc. Here, one can often state the presence of closed growth cycles. For example, in the case when the platform receives additional customers, it can use their data to better understand their demands and more accurately determine the most suitable advertising materials for them. Such activity, if done successfully, will lead to a more rapid growth.

Often the effect of such a cycle turns out to be so significant that many small and recently formed startups with no sufficient data and financial (as well as social) resources face the only real option for further development. This alternative lies in its acquisition by one of the leading companies in a particular market. To further exemplify the significance of this aspect, it is worth citing the number of all acquisitions by the four largest technological giants of our time: Google - 238; Apple - 110; Amazon.com - 86; Facebook - 81 [10]. The top 10 largest Google transactions in total exceed USD29 billion [11].

$\mathrm{M}$ odern digital companies have largely rethought the previously dominant business models and development principles. Under current conditions of the digital economy, not always profit and profitability are the main indicators of the success of the company but rather the expansion of its activities. For example, it is widely appreciated that one of the largest companies in the world at the moment, Amazon.com, did not receive any profit for a significant time during its history (which was agreed with investors). It reinvested its income in expanding and strengthening its position as much as possible in a growing and dynamic market of online commerce [12].

As for the dominance of individual products on the market, e.g., applications (Twitter, Instagram, WhatsApp, Facebook Messenger, TikTok, YouTube), we should pay attention to the psychological and behavioral aspects, the manipulation mechanisms that are "installed" into them. According to the terminology of the famous writer Nir Eyal (the author of the book "Hooked: How to Build Habit-Forming Products"), in the market of the online and digital products, the model of psychological hook, which makes customers stay, is often used.

We should briefly describe the main elements of the approach formed by the author of this book. The effect of anchoring a user to a specific product (and as a result, the company) is important enough to form a comprehensive understanding of the reasons for such an active growth of individual market players.

The 4-phase cycle of the Hook Model formed by Nir Eyal suggests that usually at the first stage the user performs a certain action (for example, opens the application having undergone external (network effects or friend's advice) or internal (association or already established habit) influence, or trigger).

Further in this cycle, aimed at creating a persistent habit to use this particular application or platform, the user performs the main action of this product. For exam- 
ple, scrolls Instagram feed or sends a greeting to a friend in the messenger.

Finally, he gets the result (variable reward) - sees the photo/video, reads a message from his friend or colleague. All this - an association with an enjoyable pastime or even efforts, investment to create content (e. g., on Instagram, YouTube or TikTok) - actively forms the so-called Hook Effect. It means that the "investment" the user makes by interacting with the product turns out to be so great, that it becomes difficult for him/her to pay attention to the ana$\log$. Therefore, even if an alternative has enhanced functionality and overall quality, the user is likely to proceed with interacting with the familiar digital product.

$\mathrm{T}$ These, and many other processes associated with digitalization of the economy, both covered and not covered in the article, raise the following question. What institutional, legislative and social actions are needed to reduce the risk of the appearance of "monopolies of the digital economy" and to avoid abuse of their position, achieved largely for the account of the dynamic growth of Internet marketing services? Here we should pay attention to several significant contradictions.

New companies, in contrast to the established understanding of a monopolist as a player with high market prices, base and strengthen their dominance by providing relevant and sought-after quality products and services, often at low prices, and sometimes even for free. Here, it may seem that the user (buyer) only benefits from such a situation, but first, we cannot exclude the factor of limiting the influx of new players and products (which would provide even better solutions), largely because they do not have the competitive advantage like economies of scale. Secondly, the company receives a wide variety of information from its users, which, on the one hand, turns it into the most valuable resource of the company, allowing it to form power over the consumer. On the other hand, it is being transformed into a resource for improving the quality of services, which can make them even more targeted, necessary and aimed at the formation of psychologically stable user habits.

Thus, in our opinion, it is worth revising the modern approach in many respects, both on the part of state bodies and civil society, regarding the main factors determining the quality and safety of services. It is necessary to take into account not only the product itself, its functionality and pricing policy but also the freedom of choice by the user, security of his/her data, privacy, the "price" for switching to another product, etc.

Among the initiatives to counteract the occurrence of such contradictions, we should mention the experience of Germany, where, in 2017, an amendment to the Act against Restraints of Competition was made to take into account the new conditions dictated by the development of the digital economy. Among other things, its Paragraph 18 (2a) declares that we cannot invalidate the statement that a certain market exists because it provides the goods or services free of charge [13]. The new law also takes into account factors preventing the user from switching to other services as well as economies of scale on the part of large players.

It is also worth paying attention to such a feature of competition in the digital economy as the desire of companies to fight for the entire market. A bright example of this behavior is the share of the Google search engine in the volume of search queries. According to the platform Statista.com, as of October 2019, it amounted to almost 88\% (though the second-ranking Bing has a share of only 5.26\%) [14]. In turn, more than USD258 billion was spent on the Amazon.com online platform during 2018, which accounted for $49.1 \%$ of all online trade in the United States. However, the second-largest e-commerce platform, eBay, had a share of only $6.6 \%$ [15].

$\mathrm{R}$ eturning to Google, we should note that not so long ago (in 2017) the European Commission fined the company EUR2.42 billion for the violation relating to the abuse of its market position. Leading in a particular market by itself, according to the law of the European Union, is not a violation. However, any abuse of neutrality and the use of a company's position to benefit (which is a priori unavailable to other players) is illegal [16].

The reason is that the Google search engine was inclined to show results promoting its product comparison service, while not allowing the user to notice the other offers. In this case, we can state nothing but a violation of the so-called "principle of neutrality", which is widespread in the telecommunications industry and among Internet providers, and shields them from the use of various illegal mechanisms to advertise their goods and services.

It is worth repeating once again that in a modern digital economy the value of an asset (for example, an innovative startup) should be measured by the volume, quality, and prospects of using the information and technological solutions at its disposal, rather than just money. The series of transactions made by Facebook can demonstrate an example of an initiative to buy smaller and possibly successful in the future company. These operations also attracted some attention of the US Federal Trade Commission at the beginning of 2019 because they let Facebook get a dominant position in other segments of the market.

We are talking about the deal of acquiring a startup in the sphere of publishing photos (Instagram) in 2012 and a messenger (WhatsApp) in 2014. We can state that at that time Facebook, as a social network, was relatively less focused on a new format of content-mobile (in the form of smartphones, tablets, etc.). The acquisition of these two companies, formed at the beginning of the active development of the era of smartphones, played a positive role in strengthening Facebook's position in the market of social networks and applications.

At the time of the acquisition, both Instagram and WhatsApp were not financially profitable companies, but 
they already gained significant appreciation from users and became popular. In April 2012, the Instagram application had over 30 million users, while over 400 million people used WhatsApp messenger, founded by Jan Koum (an American entrepreneur of Ukrainian origin) [17; 18].

\section{CONCLUSIONS}

Digitalization of the economy leads to fundamental changes at the level of individual markets and sectors, as well as innovations in the sphere of technological development. These developments significantly affect both the economy and society, changes the nature of their interaction. The digital economy is fundamentally changing the market environment. Some players can capture markets, change the rules of the game, and establish power over the consumer. Under these conditions, the nature of monopoly is changing due to the psychological anchoring of consumers to the set of certain applications and tools. Competition is constantly shifting towards the psychological mechanisms of customer retention.

Summing up, we can conclude that a deeper study of changes in the market environment and institutional reforms aimed at maintaining the security of personal data and the freedom of choice of the consumer remains an urgent and highly relevant problem.

\section{LITERATURE}

1. Santiso C. It's make or break time for GovTech investe ments. URL: https://apolitical.co/en/solution_article/ its-make-or-break-time-for-govtech-investments

2. Кузнєцова А. Я., Чмерук Г. Г. Теоретичні підходи до визначення цифрової економіки. Проблеми системного підходу в економіці. 2019. № 6. С. 34-41. URL: http://psae-jrnl.nau.in.ua/journal/6_74_1_2019_ ukr/5.pdf

3. Веретюк С. М., Пілінський В. В. Визначення пріоритетних напрямків розвитку цифрової економіки в Україні. Наукові записки Українського науководослідного інституту зв'язку. 2016. № 2. С. 51-58.

4. Кіт Л. 3. Еволюція мережевої економіки. Вісник Хмельницького національного університету. Серія «Економічні науки». 2014. № 3. Ч. 2. С. 187-194.

5. Гулей А. І., Язлюк Б. О., Гулей С. А. Формування нової цифрової ери на межі реального та віртуального соціально-економічного простору взаємодії. Український журнал прикладної економіки. 2018. T. 3. № 2. С. 17-26.

6. FT Global 500 March 2008. Prices and market valy ue at 31 March 2008. URL: http://media.ft.com/ cms/7f24a88e-0faa-11dd-8871-0000779fd2ac.pdf

7. Global Top 100 companies by market capitalization. July 2019. URL: https://www.pwc.com/gx/en/auditservices/publications/assets/global-top-100-companies-2019.pdf

8. Gesenhues A. Amazon owns more than $90 \%$ market share across 5 different product categories [Report]. URL: https://marketingland.com/amazon-owns-morethan-90-market-share-across-5-different-product-categories-report-241135
9. Is Amazon killing Barnes \& Noble's chances for a turnt around? // RetailWire. June 18, 2018. URL: https:// retailwire.com/discussion/is-amazon-killing-barnesnobles-chances-for-a-turnaround/

10. Acquisitions. Crunchbase. URL: https://www.crunchbase.com/search/acquisitions

11. Infographic: Google's Biggest Acquisitions. CBInsights. URL: https://www.cbinsights.com/research/googlebiggest-acquisitions-infographic/

12. Molla R. Amazon's tiny profits, explained. URL: https:// www.vox.com/recode/2019/8/21/20826405/amazons-profits-revenue-free-cash-flow-explained-charts

13. Act against Restraints of Competition // Bundesgesetzblatt. 26 June 2013. URL: https://www.gesetze-iminternet.de/englisch_gwb/englisch_gwb.html

14. Worldwide desktop market share of leading search engines from January 2010 to July 2019. Statista. URL: https://www.statista.com/statistics/216573/worldwide-market-share-of-search-engines/

15. Lunden I. Amazon's share of the US e-commerce market is now $49 \%$, or $5 \%$ of all retail spend. URL: https:// techcrunch.com/2018/07/13/amazons-share-of-theus-e-commerce-market-is-now-49-or-5-of-all-retailspend/

16. Antitrust: Commission fines Google $€ 2.42$ billion for abusing dominance as search engine by giving illegal advantage to own comparison shopping service. European Commission. URL: https://ec.europa.eu/commission/presscorner/detail/en/IP_17_1784

17. Protalinski E. Instagram passes 50 million users. URL: https://www.zdnet.com/article/instagram-passes50-million-users/

18. WhatsApp now has $600 \mathrm{~m}$ active users // Irish Tech News. URL: https://irishtechnews.ie/whatsapp-nowhas-600m-active-users/

\section{REFERENCES}

"Acquisitions. Crunchbase". https://www.crunchbase.com/ search/acquisitions

"Act against Restraints of Competition". Bundesgesetzblatt. 26 June 2013. https://www.gesetze-im-internet. de/englisch_gwb/englisch_gwb.html

"Antitrust: Commission fines Google €2.42 billion for abusing dominance as search engine by giving illegal advantage to own comparison shopping service". European Commission. https:/ec.europa.eu/commission/ presscorner/detail/en/IP_17_1784

"FT Global 500 March 2008. Prices and market value at 31 March 2008". http://media.ft.com/cms/7f24a88e-0faa11dd-8871-0000779fd2ac.pdf

"Global Top 100 companies by market capitalization". July 2019. https://www.pwc.com/gx/en/audit-services/publications/assets/global-top-100-companies-2019.pdf

Gesenhues, A. "Amazon owns more than 90\% market share across 5 different product categories [Report]". https://marketingland.com/amazon-owns-morethan-90-market-share-across-5-different-product-categories-report-241135

Hulei, A. I., Yazliuk, B. O., and Hulei, S. A. "Formuvannia novoi tsyfrovoi ery na mezhi realnoho ta virtualnoho sotsialno-ekonomichnoho prostoru vzaiemodii“ [A New Digital Era Formation at the Borders of Real and Virtual 
Socio-Economic Space of Interaction]. Ukrainskyi zhurnal prykladnoi ekonomiky, vol. 3, no. 2 (2018): 17-26.

"Infographic: Google's Biggest Acquisitions". CBInsights. https://www.cbinsights.com/research/google-biggest-acquisitions-infographic/

"Is Amazon killing Barnes \& Noble's chances for a turnaround?" RetailWire. June 18, 2018. https://retailwire. com/discussion/is-amazon-killing-barnes-nobleschances-for-a-turnaround/

Kit, L. Z. "Evoliutsiia merezhevoi ekonomiky" [Evolution of Network Economics]. Visnyk Khmelnytskoho natsionalnoho universytetu. Seriia «Ekonomichni nauky», vol. 2, no. 3 (2014): 187-194.

Kuznietsova, A. Ya., and Chmeruk, H. H. "Teoretychni pidkhody do vyznachennia tsyfrovoi ekonomiky" [Theoretical Approaches to Determining the Digital Economy]. Problemy systemnoho pidkhodu v ekonomitsi. 2019. http://psae-jrnl.nau.in.ua/journal/6_74_1_2019_ ukr/5.pdf

Lunden, I. "Amazon's share of the US e-commerce market is now $49 \%$, or $5 \%$ of all retail spend". https://techcrunch.com/2018/07/13/amazons-share-of-the-us-ecommerce-market-is-now-49-or-5-of-all-retail-spend/
Molla, R. "Amazon's tiny profits, explained". https://www. vox.com/recode/2019/8/21/20826405/amazons-profits-revenue-free-cash-flow-explained-charts

Protalinski, E. "Instagram passes 50 million users". https:// www.zdnet.com/article/instagram-passes-50-millionusers/

Santiso, C. "It's make or break time for GovTech investments". https://apolitical.co/en/solution_article/itsmake-or-break-time-for-govtech-investments

Veretiuk, C. M., and Pilinskyi, V. V. "Vyznachennia priorytetnykh napriamkiv rozvytku tsyfrovoi ekonomiky v Ukraini" [Determination of the Priority Directions for Digital Economy's Development in Ukraine]. Naukovi zapysky Ukrainskoho naukovo-doslidnoho instytutu zviazku, no. 2 (2016): 51-58.

"WhatsApp now has 600m active users". Irish Tech News. https://irishtechnews.ie/whatsapp-now-has-600mactive-users/

"Worldwide desktop market share of leading search engines from January 2010 to July $2019^{\prime \prime}$. Statista. https:// www.statista.com/statistics/216573/worldwide-market-share-of-search-engines/ 